\title{
Effect of Dams and Suckling Lamb Feeding Systems on the Fatty Acid Composition of Suckling Lamb Meat
}

\author{
Gianni Battacone (D), Mondina Francesca Lunesu*(D), Salvatore Pier Giacomo Rassu, Giuseppe Pulina (D) \\ and Anna Nudda (D)
}

Citation: Battacone, G.; Lunesu, M.F.; Rassu, S.P.G.; Pulina, G.; Nudda, A. Effect of Dams and Suckling Lamb Feeding Systems on the Fatty Acid Composition of Suckling Lamb Meat. Animals 2021, 11, 3142. https:// doi.org/10.3390/ani11113142

Academic Editors: Antonino Di Grigoli and Adriana Bonanno

Received: 14 July 2021

Accepted: 2 November 2021

Published: 3 November 2021

Publisher's Note: MDPI stays neutral with regard to jurisdictional claims in published maps and institutional affiliations.

\author{
Dipartimento di Agraria, Sezione di Scienze Zootecniche, University of Sassari, Viale Italia 39, 07100 Sassari, Italy; \\ battacon@uniss.it (G.B.); pgrassu@uniss.it (S.P.G.R.); gpulina@uniss.it (G.P.); anudda@uniss.it (A.N.) \\ * Correspondence: mflunesu@uniss.it; Tel.: +39-079-229-308
}

Simple Summary: Suckling lamb meat is one of the most relevant products of the Mediterranean traditional dairy sheep industry. Being lamb fed exclusively with maternal milk, meat quality is mainly affected by the mother's milk composition and hence by the mother feeding during gestation and lactation. This paper summarizes the state of the art about the effect of the dam and suckling lamb feeding systems on lamb meat quality, with special attention to the lipid fraction considered beneficial to human health.

\begin{abstract}
The effects of the dams and suckling lamb feeding systems on the fatty acid (FA) profile of lamb meat are reviewed in this article. The suckling lamb can be considered a functional monogastric, and therefore, its meat FA composition is strongly influenced by the FA composition of maternal milk. The major source of variation for ewe milk FA composition is represented by pasture amount and type. In the traditional sheep breeding system of the Mediterranean area, the main lambing period occurs in late autumn-early winter, and ewes are able to exploit the seasonal availability of the natural pastures at their best. Therefore, lambs start suckling when maternal milk concentrations of vaccenic, rumenic, and n-3 long-chain polyunsaturated FA in maternal milk are the highest. When maternal diet is mainly based on hay and concentrates, the use of vegetable oils can be considered a good strategy to improve the meat FA profile of suckling lambs.
\end{abstract}

Keywords: suckling lamb; meat fatty acid; grass; maternal diet

\section{Introduction}

Sheep productions (milk, meat, and wool) are among the principal agricultural activities of the Mediterranean Area, where they play a prominent socio-economic role because of their strong link with the territory [1]. Despite its ancient origin, the current sheep industry is characterized by a high level of multifunctionality, integrating food security and safety, animal welfare, environmental sustainability, ecosystem services, and biodiversity preservation. World meat production, including sheep meat, is expected to double by 2050 [2], due to the growing population and incomes. Thus, special attention should be paid to meat quality.

Suckling lamb meat is a typical product of the Mediterranean countries where dairy sheep farming is widespread, with milk as the main and lamb meat as the secondary products [3,4]. Suckling lambs are fed only maternal milk, and they are slaughtered at 4-6 weeks of age with a body weight of 9-11 kg [3,5-7]. Even if the traditional suckling is the most common, artificial suckling with milk replacer or partial suckling systems are sometimes used to increase the amount of milk available for cheese processing and to improve lamb survival $[8,9]$.

The suckling lamb can be considered a functional monogastric due to the underdevelopment of rumen. Thus, meat quality strongly depends on maternal milk composition $[3,10,11]$. For this reason, research on dairy sheep breeds has focused on milk 
nutritional and technological properties in order to improve firstly the quality of dairy products [1] but also of suckling lamb meat. The fat and fatty acids (FA) profiles of maternal milk strongly affect meat FA profile with consequences on its nutritional and sensory characteristics. Sheep milk is rich in potentially healthy FA, especially rumenic (RA; C18:2c9,t11; also named c9,t11-conjugated linoleic acid or $\mathrm{c} 9, \mathrm{t} 11$-CLA), vaccenic (VA; C18:1t11), linolenic (ALA; C18:3n3) [12], and branched-chain fatty acids (BCFA) [13].

Currently, there is a growing number of health-aware consumers that require meat with less fat, lower levels of saturated fatty acids (SFA), and higher content of FA of nutritional interest. It is widely assessed that the intramuscular FA profile of suckling lambs reflects that of their mother's milk. Thus, the diet composition during pregnancy [14] and/or lactation $[3,7,15-17]$ can affect meat characteristics.

For this reason, several studies on the modification of fat content and FA composition of lamb meat have been carried out. The role of this review is to provide advanced updates about relationships between the FA profile of suckling lamb meat and feeding systems of dams and suckling lambs aimed at improving the ewe-milk-fed suckling lamb meat.

\section{The Quality of Sucking Lamb Fat}

Suckling lamb meat represents an important source of lipids and provides some FA that are involved in many biological activities connected to the health status [18], especially essential FA [19] and specific long-chain polyunsaturated fatty acids (LC-PUFA), which are crucial for normal fetal development and neonatal growth [20,21]. In addition, lamb is the first meat recommended by Italian pediatricians in the weaning diet of children because it is presumed to have lower allergenicity, compared with other red meats [22,23].

Among the different types of meat, suckling lamb meat contains a low amount of intramuscular fat (Table 1; around 2-3\%), which are composed of $41-46 \%$ of SFA, $42-43 \%$ of monounsaturated fatty acids (MUFA) and $15-11 \%$ of PUFA $[3,24]$. On the basis of this composition, it can be classified as extra-lean meat as defined by FDA [25], with less than $5 \mathrm{~g}$ of fat and $2 \mathrm{~g}$ of SFA in $100 \mathrm{~g}$ of meat, respectively. The predominant FA in suckling lamb meat are oleic (OLA; C18:1c9), followed by palmitic (PA; C16:0) and stearic (SA;C18:0) acids, in line with the FA profile of commercial lamb meat from the typical production systems of Italy [26-28], Spain, Germany, United Kingdom, and Uruguay [29].

Table 1. Fatty acid composition of intramuscular lipid (\% of total fatty acids) in suckling lambs from the extensive system, heavy lambs reared in the intensive system, and mature ewes.

\begin{tabular}{cccc}
\hline Item $^{\mathbf{1}}$ & Suckling Lambs $^{\mathbf{2}}$ & Heavy Lamb $^{\mathbf{3}}$ & Mature Ewes $^{\mathbf{4}}$ \\
\hline Fat content, \% & 1.93 & 2.86 & 3.27 \\
C14:0 (Myristic acid, MA) & 3.72 & 4.41 & 1.85 \\
C14:1c9 & 0.15 & 0.13 & 0.10 \\
isoC14:0 & 0.04 & 0.05 & 0.02 \\
isoC15:0 & 0.12 & 0.10 & 0.12 \\
anteisoC15:0 & 0.18 & 0.17 & 0.13 \\
C15:0 & 0.45 & 0.52 & 0.42 \\
C15:1c10 & 0.00 & n.d. & 0.15 \\
isoC16:0 & 2.60 & 0.16 & 0.07 \\
C16:0 (Palmitic acid, PA) & 16.53 & 20.57 & 24.47 \\
C16:1c7 $16: 1 c 9$ & 0.48 & 0.47 & 0.29 \\
isoC17:0 & 1.23 & 1.44 & 1.16 \\
anteisoC17:0 & 0.51 & 0.40 & 0.46 \\
C17:0 & 0.40 & 0.48 & 0.60 \\
\hline
\end{tabular}


Table 1. Cont.

\begin{tabular}{|c|c|c|c|}
\hline Item $^{1}$ & Suckling Lambs ${ }^{2}$ & Heavy Lamb ${ }^{3}$ & Mature Ewes $^{4}$ \\
\hline C17:1c9 & 0.43 & 0.47 & 0.46 \\
\hline isoC18:0 & n.d. & 0.12 & 0.15 \\
\hline C18:0 (Stearic acid, SA) & 12.16 & 16.82 & 18.22 \\
\hline C18:1t9 (Elaidic acid, EA) & 0.22 & 0.37 & 0.18 \\
\hline $\mathrm{C} 18: 1 \mathrm{t} 10$ & 0.36 & 3.75 & 0.32 \\
\hline C18:1t11 (Vaccenic acid, VA) & 1.86 & 1.48 & 2.01 \\
\hline $\mathrm{C} 18: 1 \mathrm{t} 12$ & 0.00 & 0.84 & 0.00 \\
\hline C18:1c9 (Oleic acid, OLA) & 29.20 & 30.94 & 37.47 \\
\hline C18:1c11 & 1.42 & 1.10 & 0.97 \\
\hline C18:1c12 & 0.44 & 0.47 & 0.21 \\
\hline C18:1c13 & 0.10 & 0.14 & 0.11 \\
\hline C18:1c14 & 0.00 & 0.08 & \\
\hline C18:1c15 & 0.14 & 0.09 & 0.18 \\
\hline C18:2n6 (Linoleic acid, LA) & 8.84 & 4.98 & 4.34 \\
\hline C18:3n3 (Linolenic acid, ALA) & 1.97 & 1.03 & 0.92 \\
\hline c9,t11-CLA (Rumenic acid, RA) & 1.16 & 0.62 & 0.84 \\
\hline C20:2n6 & 0.08 & 0.04 & 0.04 \\
\hline C20:4n6 (Arachidonic acid, ARA) & 3.63 & 1.07 & 0.04 \\
\hline C20:3n3 & 0.05 & 0.01 & 0.97 \\
\hline C20:5n3 (Eicosapentaenoic acid, EPA) & 1.16 & 0.23 & 0.07 \\
\hline $\mathrm{C} 22: 0$ & 0.04 & 0.03 & 0.00 \\
\hline $\mathrm{C} 22: 4 \mathrm{n} 6$ & 0.23 & 0.08 & 0.05 \\
\hline C22:5n3 (Docosapentaenoic acid, DPA) & 1.45 & 0.34 & 0.18 \\
\hline C22:6n3 (Docosahexaenoic acid, DHA) & 0.86 & 0.13 & 0.00 \\
\hline SFA & 38.21 & 43.76 & 46.84 \\
\hline MUFA & 37.62 & 43.69 & 53.04 \\
\hline PUFAn3 & 5.58 & 1.78 & 1.17 \\
\hline PUFAn6 & 13.44 & 7.78 & 4.77 \\
\hline OCFA & 1.22 & 1.76 & 1.66 \\
\hline BCFA & 3.86 & 1.47 & 1.49 \\
\hline $\mathrm{n} 6 / \mathrm{n} 3$ & 2.60 & 4.08 & 4.14 \\
\hline
\end{tabular}

${ }^{1}$ SFA $=$ saturated fatty acids; MUFA = monounsaturated fatty acids; PUFAn3 = polyunsaturated fatty acids omega3; PUFAn6 = polyunsaturated fatty acids omega6; OCFA = odd-chain fatty acids; BCFA = branched-chain fatty acids; $\mathrm{n} 6 / \mathrm{n} 3=$ omega6/omega3 ratio. ${ }^{2}$ Source: $[3,7,26] .{ }^{3}$ Source: [30]. ${ }^{4}$ Source: [28]. ${ }^{5}$ n.d. $=$ not determined.

The high content of OLA in suckling lamb meat is of nutritional interest because of its positive role in the prevention of cardiovascular, autoimmune, and inflammation diseases [31,32]. The content of SFA in suckling lamb meat, composed mainly by PA and SA in similar proportion, is lower than that of heavier and adult sheep (Table 1). Recently, the role of all SFA in human health has been reconsidered because it has been reported that all types of FA, including SFA, are not related to cardiovascular disease mortality, and saturated fat is inversely associated with stroke [33]. In addition, it has been assessed that PA, which accounts for $20-30 \%$ of total human body FA and that was for a long time associated with negative health effects [18], has several essential and positive physiological properties [34]. SA, which accounted for about $6.5-13 \%$ of total FA in the meat of suckling lamb $[3,26]$, can be considered neutral for cholesterol metabolism probably because it is rapidly converted into OLA [35,36].

Regarding the unsaturated FA (UFA) profile, suckling lamb meat has a sufficient amount of both $\mathrm{n} 3$ and $\mathrm{n} 6 \mathrm{FA}$ and its $\mathrm{n} 6 / \mathrm{n} 3$ ratio is close to the optimal value of 5:1 (Table 1), which is markedly lower than that typical of Western diet (15:1 to 20:1) [37]. Moreover, the level of LC-PUFA is higher than in fatter or heavier lambs (Table 1) or in adult sheep. In fact, PUFA of both the omega3 and omega6 families are preferentially incor- 
porated in membrane phospholipids rather than in triglycerides [38], and the proportion of phospholipids on total lipids decreases with the age and fatness of the animals [39]. For the same reason, the proportion of this LC-PUFA increases in cooked meat due to the loss during cooking, mainly of triglycerides fraction that contains comparatively more SFA than UFA [3]. The meat of suckling lamb contains a higher amount of ALA, arachidonic (ARA; C20:4n6), eicosapentaenoic (EPA; C20:5n3; 13-fold higher), docosapentaenoic (DPA; C22:5n3), docosahexaenoic (DHA; C22:6n3; 4-fold higher) acids and, in general, of PUFA of the omega3 family (PUFAn3) than the meat of adult sheep [28]. Arachidonic acid, as a constituent of phospholipids membrane, is important for the function of all cells [40] and, together with DHA, favors the development and function of the nervous and visual system [20]. However, ARA metabolites could contribute both to cardiovascular and neurodegenerative diseases [41]. The ARA and DHA derive directly from the FA of the diet or through elongation and desaturation of their dietary precursors ALA and linoleic acid (LA; C18:2n6), respectively [42]. Although most scientific researchers have focused on PUFA, the role of other FA should not be neglected. Noteworthy FA in suckling lamb meat are the odd-chain FA (OCFA) and BCFA. These FA are considered biomarkers of rumen microbial fermentation and their amount in the meat of suckling lambs, which are still functional monogastric, is likely related to their concentration in the maternal milk [13]. The odd- and branched-chain fatty acids (OBCFA), not considered for a long time because of their low content in the total fat, have recently received increasing attention in human nutrition due to their potential health properties. The BCFA tested in animal models showed anti-inflammatory properties [43,44], and antitumoral activity in human breast cancer cells [45,46]. The main OCFA, C17:0 and C15:0 showed protective effects against cardiovascular disease [47-51] and contrast occurrence of type 2 diabetes [52-55]. A recent study demonstrated that $\mathrm{C} 15: 0$ has a direct role in attenuating multiple comorbidities in humans as inflammation, anemia, and dyslipidemia [56]. Lamb meat, together with dairy foods, represents the main source of both OCFA and BCFA in the human diet [13].

Meat represents also one of the main sources of VA and c9,t11-CLA in the human diet. The content of $\mathrm{c} 9, \mathrm{t} 11-\mathrm{CLA}$ in suckling lamb meat is in line with those reported in other studies on suckling [26] and weaned lambs [38]. Clinical and animal studies have suggested anti-inflammatory and immunomodulatory antiatherogenic activities of c9,t11-CLA [57-59], as well as lowering cholesterol [60-62] and hyperinsulinemia prevention $[63,64]$ effects. The anticarcinogenic effect of $c 9, t 11$-CLA has been widely observed in several studies on cell cancer lines and laboratory animals [58], but these results need to be confirmed in humans.

Changes in the UFA level in meat lead to the production of different amounts and types of volatile compounds (VOCs), which can affect the sensory properties of suckling lamb meat. The oxidation of PUFA, present in high proportion in suckling lamb meat, might produce aldehydes, as pentanal and hexanal from LA and ALA, heptanal and octanal from OLA and LA, and nonanal from OLA [65]. These compounds are usually related to the overall positive acceptability of flavor, because they have low odor detection thresholds [66].

\section{Suckling Lamb Feeding System and Meat Fatty Acid Profile}

\subsection{Suckling Lambs from Ewes Grazing on Pasture}

Meat and milk derived from animals reared in pasture-based farming systems are highly appreciated by the consumers due to the perception of greater welfare of the grazing animals and to the superior quality of animal-derived products [67]. This is true especially for the suckling lamb of the Mediterranean area, where consumer responses highlighted that meat of lambs nursed by mothers fed on pasture was preferred to meat from lambs of indoor-fed mothers $[67,68]$. 
From a nutritional point of view, suckling lamb meat from pasture-fed mothers exhibits an FA profile more favorable for human health than suckling lamb meat from stall-fed mothers (hay and concentrate) (Figure 1). In particular, meat of lambs of pasture-fed mothers shows a larger content of PUFA, especially of the $\mathrm{n} 3$ family including ALA but also LC-PUFAn3, with a marked reduction in $\mathrm{n} 6 / \mathrm{n} 3$ ratio. In addition, an increase in VA and RA has been also detected in lambs from pasture-fed mothers. These differences are partly related to maternal milk FA composition (Table 2), and they depend on the transfer from grass to milk [69], then to the meat of suckling animals, of the compounds beneficial for human health.

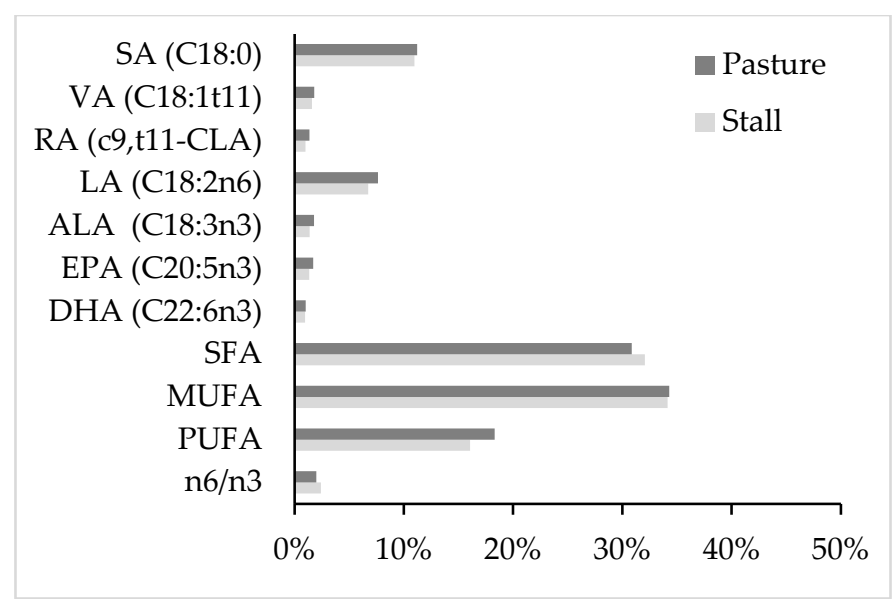

(a)

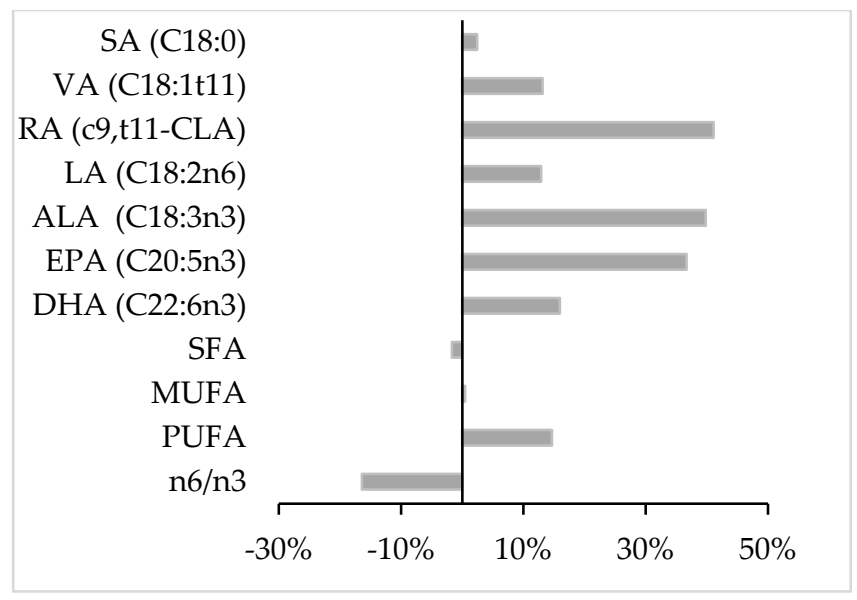

(b)

Figure 1. Effect of pasture- or stall-fed mothers on intramuscular fatty acid profile of suckling lamb meat. -Data are reported as \% of total fatty acids (a) and as the proportional difference (\%) between the pasture group and the control group (b). SA = stearic acid (C18:0), VA = vaccenic acid (C18:1t11), RA = rumenic acid (c9,t11-CLA), LA = linoleic acid (C18:2n6), $\mathrm{ALA}=\alpha$-linolenic acid (C18:3n3), EPA = eicosapentaenoic acid (C20:5n3), DHA = docosahexaenoic acid (C22:6n3), SFA = saturated fatty acids, MUFA = monounsaturated fatty acids, PUFA = polyunsaturated fatty acids. References: [11,67,70-73]. 
Table 2. Milk fatty acid profile of pasture- and stall-fed mothers.

\begin{tabular}{|c|c|c|c|c|c|c|c|c|c|c|c|c|c|c|c|c|c|}
\hline \multirow[b]{2}{*}{ Breed } & \multirow[b]{2}{*}{ Treatment } & \multicolumn{15}{|c|}{ Fatty Acid Composition of Ewe Milk (\% on Total Fatty Acids) ${ }^{1}$} & \multirow[b]{2}{*}{ References } \\
\hline & & $\begin{array}{c}\text { PA } \\
(\mathrm{C} 16: 0)\end{array}$ & $\begin{array}{c}\text { SA } \\
(\mathrm{C} 18: 0)\end{array}$ & $\begin{array}{c}\text { VA } \\
\text { (C18:1t11) }\end{array}$ & $\begin{array}{c}\text { RA } \\
\text { (c9,t11-CLA) }\end{array}$ & $\begin{array}{c}\text { LA } \\
\text { (C18:2n6) }\end{array}$ & $\begin{array}{c}\text { ALA } \\
\text { (C18:3n3) }\end{array}$ & $\begin{array}{c}\text { EPA } \\
(\mathrm{C} 20: 5 \mathrm{n} 3)\end{array}$ & $\begin{array}{c}\text { DHA } \\
\text { (C22:6n3) }\end{array}$ & SFA & MUFA & PUFA & PUFA/SFA & n6 & n3 & n6/n3 & \\
\hline \multirow{3}{*}{$\begin{array}{l}\text { Churra } \\
\text { Tensina }\end{array}$} & Hay Pre-partum & 21.04 & 13.30 & - & 1.36 & - & 1.44 & 0.11 & 0.07 & 56.15 & 31.34 & 5.80 & 0.10 & 2.54 & 1.61 & 1.62 & \multirow{3}{*}{ [73] } \\
\hline & Hay post-partum & $21.17 \uparrow$ & 12.96 & - & 1.29 & - & 1.4 & 0.104 & 0.074 & 56.37 & 31.61 & 5.70 & 0.10 & 2.53 & 1.58 & $1.64 \uparrow$ & \\
\hline & Pasture postpartum & 20.24 & $14.40 \uparrow$ & - & $1.63 \uparrow$ & - & $1.57 \uparrow$ & 0.11 & 0.068 & 56.17 & 29.93 & $6.19 \uparrow$ & $0.11 \uparrow$ & 2.48 & $1.74 \uparrow$ & 1.46 & \\
\hline \multirow{2}{*}{$\begin{array}{l}\text { Churra } \\
\text { Tensina }\end{array}$} & Hay fed mothers & - & - & - & 1.29 & - & - & - & - & 56.37 & 31.61 & 5.70 & 0.10 & 2.53 & 1.58 & $1.64 \uparrow$ & \multirow{2}{*}{ [72] } \\
\hline & Pasture fed mothers & - & - & - & $1.63 \uparrow$ & - & - & - & - & 56.17 & 29.93 & $6.19 \uparrow$ & $0.11 \uparrow$ & 2.48 & $1.74 \uparrow$ & 1.46 & \\
\hline Merino & Pasture fed mothers & 18.38 & 11.48 & $1.70 \uparrow$ & 1.33 & 3.11 & $4.46 \uparrow$ & - & - & 65.26 & 23.89 & $10.85 \uparrow$ & $0.17 \uparrow$ & - & - & - & {$[71]$} \\
\hline \multirow{3}{*}{ Massese } & $\begin{array}{l}\text { Stall (reared indoor fed } \\
\text { concentrate and hay) }\end{array}$ & 25.15 & 8.60 & - & - & 2.35 & 0.87 & 0.13 & 0.09 & 73.10 & 22.07 & 3.95 & - & 2.86 & 1.09 & - & \multirow{3}{*}{ [74] } \\
\hline & $\begin{array}{l}\text { Semi free-range (reared } \\
\text { indoors during the night, } \\
\text { fed concentrate, hay, and } \\
\text { herbage) }\end{array}$ & 23.57 & 12.41 & - & - & 2.73 & 1.38 & 0.18 & 0.09 & 70.94 & 23.19 & 4.78 & - & 3.13 & 1.65 & - & \\
\hline & $\begin{array}{l}\text { Pasture (reared outdoor } \\
\text { and fed pasture and hay) }\end{array}$ & 23.71 & $15.85 \uparrow$ & - & - & 2.62 & $2.18 \uparrow$ & 0.23 & $0.23 \uparrow$ & $63.18 \downarrow$ & $29.33 \uparrow$ & $6.09 \uparrow$ & - & 3.43 & $2.66 \uparrow$ & - & \\
\hline
\end{tabular}

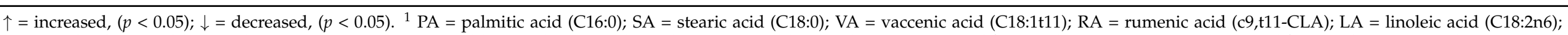

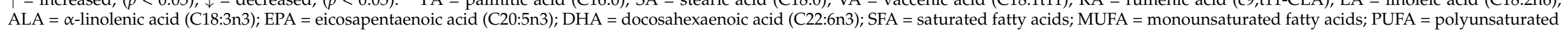
fatty acids; $6 / \mathrm{n} 3=$ omega $6 /$ omega3 ratio 
Plants are the primary source of essential PUFAn3, especially ALA, which is partly biohydrogenated into VA in the rumen and then secreted into milk and partially converted into c9,t11-CLA in the mammary tissue by the action on VA by stearoyl-CoA desaturase [75]. The essential ALA present in milk is partly incorporated into tissues of suckling lambs as is. On the other hand, milk has a very limited content of LC-PUFA due to the high level of rumen biohydrogenation [76], to the low activity of elongation and desaturation in the mammary gland of FA with 18 and 20 carbon atoms, and also because these LC-PUFA are not transported with the plasma lipid fractions, which are the main mammary sources of FA uptake [77]. However, muscle tissue — even if at a limited extent—has the capacity to further metabolize ALA to EPA and DHA [78] by $\Delta 6$ desaturases and $\Delta 5$ desaturases, respectively, determining the observed favorable increase in LC-PUFA (Figure 1b).

However, the pasture effects on milk and, consequently, on meat c9,t11-CLA, and PUFAn3 contents depend on the seasonal variation of forage quality and the botanical composition of herbage $[79,80]$. In terms of seasonal variations, the best FA composition of grass can be reached during the vegetative phase, whereas during the reproductive phase the concentration of ALA falls dramatically [80,81]. The quantity and quality of pasture availability for ewes could be the underlying reason for variation in the FA profile of suckling lamb meat reared in different seasons [7]. This last study reported an interesting variation in OCFA and BCFA, which were higher in meat from lambs reared in spring than winter season ( $4.72 \mathrm{vs.} 3.95 \mathrm{~g} / 100 \mathrm{~g}$ of fat, respectively). The intake of small amounts of herbage by the suckling animals that follow the mother on pasture might occur early during spring than winter season, causing an earlier development of the forestomach fermentation system. Surprisingly, no variation in PUFAn3 has been observed in the meat of suckling lambs reared in winter or spring.

In view of these considerations, the traditional Mediterranean breeding system, where lambing occurs in late autumn-early winter allows ewes to exploit the seasonal availability of the natural and cultivated pastures. Therefore, lambs are mainly nursed when maternal milk's FA contents of nutritional interest such as VA, RA, PUFAn3, LC-PUFA, and OBCFA are at the highest level.

\subsection{Suckling Lambs Fed Maternal Milk or Milk Replacers}

Artificial rearing based on the use of milk replacers is used to increase the amount of commercial milk sold to cheese-making companies $[9,82]$.

The composition of lamb meat reflects that of maternal milk (Table 3), which, compared with commercial milk replacers, is richer in c9,t11-CLA, VA, ALA, EPA, DHA $[8,24,83,84]$, and also in OBCFA, which are from three- to tenfold higher [24].

From a nutritional and healthy point of view, suckling lamb meat, compared with artificially reared ones (Table 4$)$, presents a more favorable nutritional FA profile since it contains more c9,t11-CLA $(+79 \%)$, VA $(+760 \%)$, ALA $(+256 \%)$, EPA $(+188 \%)$, and DHA $(+117 \%)$. On the other hand, the use of artificial rearing increases the total PUFA $[8,10]$ because most of the fat components of artificial milk are derived from vegetable oils (coconut or palm oils), which are characterized by a lower level of saturation, compared with animal fats. In addition, artificial rearing also increases the tocopherol content that is commonly added as an ingredient in the milk replacer [85].

Although the ratio of PUFA/SFA is higher in the artificially than naturally reared lambs $[8,10,83]$, maternal milk presents an acceptable range of $\mathrm{n} 6 / \mathrm{n} 3$ ratio than that of milk replacer, which generally reaches values above the recommended maximum of $4[10,86]$.

In view of these considerations, the traditional rearing system remains the best strategy to enhance the milk FA profile and the lamb meat composition from a nutritional point of view through the manipulation of the mother's diet.

Nevertheless, in our previous study, few differences were found in the meat of lambs fed with both maternal milk (only at night) and concentrate (during the day, compared with lambs fed with only maternal milk [9] — the lack of differences was not a surprise, as both groups received milk from pasture-fed mothers. 
Table 3. Fatty acid composition of maternal milk and milk replacer.

\begin{tabular}{|c|c|c|c|c|c|c|c|c|c|c|c|}
\hline \multirow{2}{*}{ Type of Milk } & \multicolumn{10}{|c|}{ Fatty Acid Composition of Suckled Milk (\% on Total Fatty Acids) ${ }^{1}$} & \multirow{2}{*}{ References } \\
\hline & SA (C18:0) & RA (c9,t11-CLA) & LA (C18:2n6) & ALA (C18:3n3) & EPA (C20:5n3) & DHA (C22:6n3) & SFA & MUFA & PUFA & $\mathrm{n} 6 / \mathrm{n} 3$ & \\
\hline Maternal milk & 12.43 & - & 1.55 & 1.40 & n.d. & 0.15 & 66.37 & 20.07 & 6.19 & 1.64 & \multirow{2}{*}{ [10] } \\
\hline Milk replacer & 13.56 & - & 4.71 & 0.49 & 0.91 & 0.13 & 60.23 & 30.11 & 9.66 & 4.39 & \\
\hline Maternal milk & 10.74 & 1.23 & 1.66 & 2.81 & - & - & 72.38 & 21.01 & 5.69 & 0.59 & \multirow{2}{*}{ [8] } \\
\hline Milk replacer & 10.14 & 0.50 & 8.30 & 1.07 & - & - & 66.15 & 23.27 & 10.12 & 7.95 & \\
\hline Maternal milk & 10.10 & 0.99 & 2.85 & 0.97 & - & - & 69.77 & 24.36 & 5.76 & 3.37 & \multirow{2}{*}{ [24] } \\
\hline Milk replacer & 11.44 & 0.38 & 5.60 & 0.25 & - & - & 60.04 & 33.66 & 7.20 & 24.21 & \\
\hline Maternal milk & 10.43 & 4.93 & 2.90 & 0.94 & 0.05 & 0.04 & 61.49 & 31.60 & 1.22 & 2.71 & \multirow{2}{*}{ Our data } \\
\hline Milk replacer & 4.17 & 0.04 & 8.67 & 1.18 & n.d. & n.d. & 52.67 & 35.56 & 1.26 & 7.66 & \\
\hline
\end{tabular}

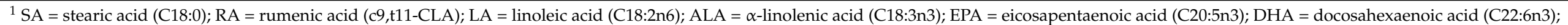

SFA = saturated fatty acids; MUFA = monounsaturated fatty acids; PUFA = polyunsaturated fatty acids; n6 $/ \mathrm{n} 3=$ omega6 $/$ omega3 ratio; .d. $=$ not detected.

Table 4. Intramuscular fatty acid profile of meat from suckling lambs of maternal or artificial milk.

\begin{tabular}{|c|c|c|c|c|c|c|c|c|c|c|c|c|c|}
\hline \multirow[b]{2}{*}{ Breed } & \multirow{2}{*}{$\begin{array}{c}\text { Type of Rearing } \\
\text { System }\end{array}$} & \multicolumn{11}{|c|}{ Fatty Acid Composition of Intramuscular Suckling Lamb Meat (\% on Total Fatty Acids) ${ }^{1}$} & \multirow[b]{2}{*}{ References } \\
\hline & & $\begin{array}{c}\text { SA } \\
\text { (C18:0) }\end{array}$ & $\begin{array}{c}\text { VA } \\
\text { (C18:1t11) }\end{array}$ & $\begin{array}{c}\text { RA } \\
\text { (c9,t11-CLA) }\end{array}$ & $\begin{array}{c}\text { LA } \\
\text { (C18:2n6) }\end{array}$ & $\begin{array}{c}\text { ALA } \\
\text { (C18:3n3) }\end{array}$ & $\begin{array}{c}\text { EPA } \\
(\mathrm{C} 20: 5 \mathrm{n} 3)\end{array}$ & $\begin{array}{c}\text { DHA } \\
\text { (C22:6n3) }\end{array}$ & SFA & MUFA & PUFA & n6/n3 & \\
\hline \multirow{2}{*}{ Comisana } & Artificial & 14.00 & - & - & 8.48 & 0.42 & 0.18 & 0.17 & 43.2 & 43.2 & 13.6 & 9.5 & \multirow{2}{*}[10]{} \\
\hline & Traditional & 12.83 & - & - & 4.05 & 1.37 & 0.62 & 0.45 & 46.6 & 41.8 & 11.6 & 2.0 & \\
\hline \multirow{2}{*}{ Sarda } & Artificial & 11.33 & - & - & 10.51 & 0.53 & 0.21 & 0.28 & 43.9 & 38.7 & 17.3 & 9.9 & \multirow{2}{*}{ [86] } \\
\hline & Traditional & 11.37 & - & - & 7.63 & 0.69 & 0.40 & 0.35 & 50.3 & 34.5 & 15.2 & 6.0 & \\
\hline \multirow{2}{*}{ Barbaresca } & Artificial & 11.64 & - & 0.47 & 18.47 & 0.37 & 0.80 & 0.53 & 34.1 & 33.3 & 32.6 & 9.7 & \multirow{2}{*}{ [8] } \\
\hline & Traditional & 12.02 & - & 1.13 & 10.97 & 1.95 & 1.65 & 1.25 & 37.7 & 34.9 & 27.4 & 2.6 & \\
\hline Churra & Traditional & 12.53 & - & 0.51 & 8.44 & 1.30 & 1.44 & - & 40.5 & 39.9 & 19.7 & 5.2 & [24] \\
\hline \multirow[b]{2}{*}{ Slovak } & Artificial & 10.14 & 0.11 & 0.15 & 9.07 & 0.25 & 0.06 & 0.08 & 44.7 & 42.5 & 12.7 & 3.5 & \multirow{2}{*}{ [83] } \\
\hline & Traditional & 12.68 & 0.96 & 0.67 & 4.81 & 0.72 & 0.35 & 0.25 & 45.6 & 43.3 & 11.1 & 1.4 & \\
\hline \multirow[b]{2}{*}{ Sarda } & Artificial & 8.47 & 0.00 & 0.08 & 15.56 & 0.82 & 0.45 & 0.52 & 35.3 & 40.8 & 23.9 & 8.0 & \multirow{4}{*}{ Our data } \\
\hline & Traditional & 13.07 & 2.34 & $\begin{array}{l}.00 \\
1.63\end{array}$ & 5.08 & $\begin{array}{l}.02 \\
1.26\end{array}$ & 0.66 & 0.59 & 44.6 & 44.8 & 10.6 & 2.1 & \\
\hline \multirow[t]{2}{*}{ Average } & Artificial & 10.66 & 0.06 & 0.34 & 11.68 & 0.42 & 0.33 & 0.26 & 39.2 & 41.4 & 19.4 & 9.5 & \\
\hline & Traditional & 12.42 & 1.65 & 0.98 & 6.83 & 1.22 & 0.85 & 0.48 & 44.2 & 39.8 & 15.9 & 3.2 & \\
\hline
\end{tabular}

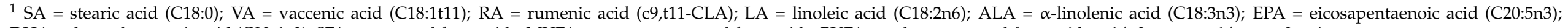

DHA = docosahexaenoic acid (C22:6n3); SFA = saturated fatty acids; MUFA = monounsaturated fatty acids; PUFA = polyunsaturated fatty acids; n6/n3 = omega6 $/$ omega3 ratio. 


\subsection{Suckling Lambs from Ewes Fed Diets Containing Vegetable or Marine Oils}

The dietary supplementation of ewes during pregnancy or at lambing with vegetable or marine oils could positively affect ewe and lamb fatty acid status, neonatal behavior and growth performance of lambs, and colostrum production $[87,88]$. However, the use of oils, particularly when the mother's diet is based mainly on hay and concentrates or whenever the availability and the quality of pasture is low, could be also an effective strategy to improve the meat FA profile of suckling lambs. However, the information found in the scientific literature is quite inconsistent, and studies deal mainly with linseed supplementation.

Linseed is the most widely used lipid supplement to test the effect of maternal diet on FA profile of intramuscular $[11,17,89,90]$ and subcutaneous fat of suckling lamb because linseed is rich in ALA [12]. Linseed inclusion, both as oil or in extruded form, strongly ameliorates the FA profile, especially at the intramuscular fat level (Figure 2; Table 5).

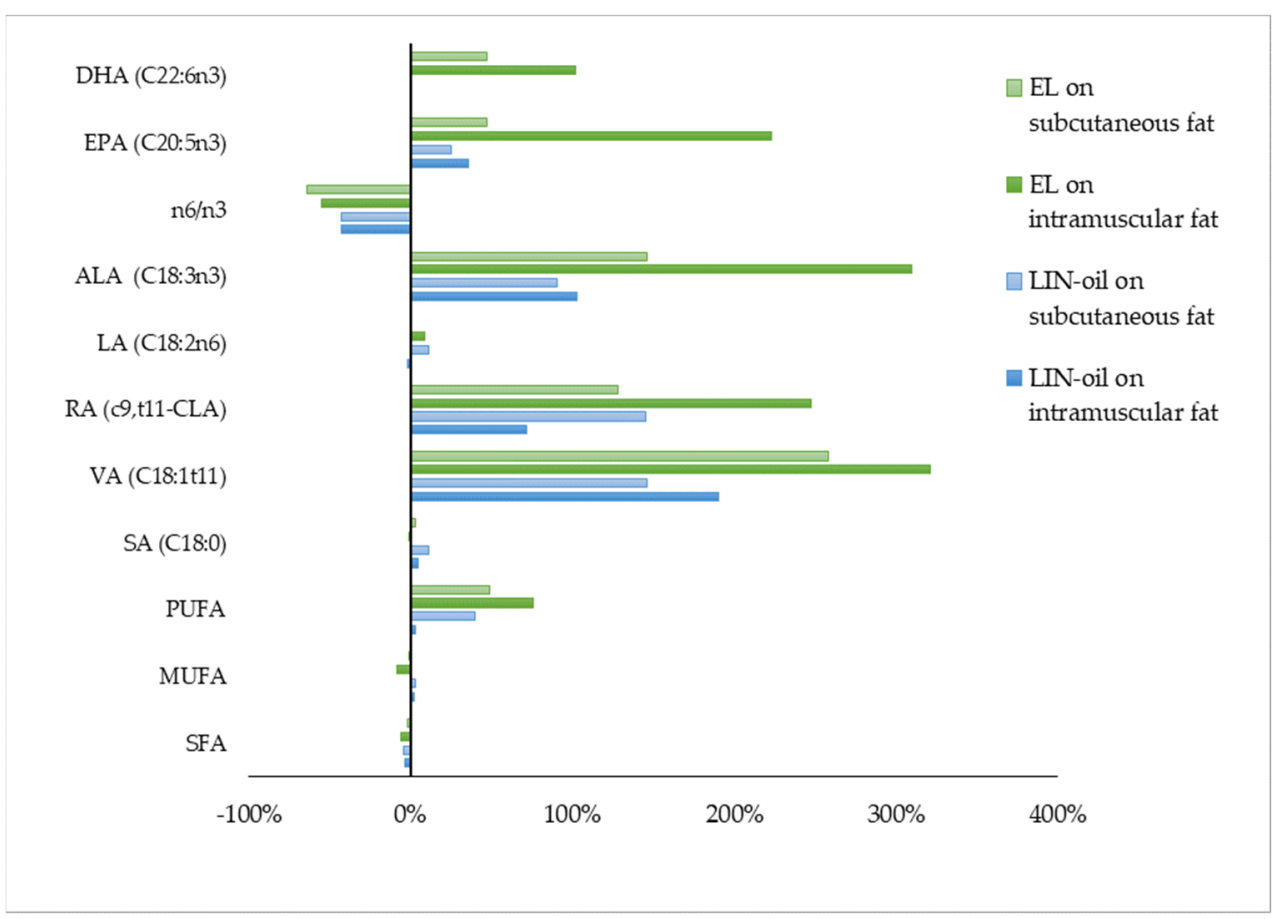

Figure 2. Effect of linseed oil (LIN-oil) or extruded linseed (EL) on intramuscular and subcutaneous fatty acid profile of suckling lamb meat. Data are reported as the proportional difference $(\%)$ between the treatment group and the control group. DHA = docosahexaenoic acid (C22:6n3), EPA = eicosapentaenoic acid (C20:5n3), ALA = $\alpha$-linolenic acid (C18:3n3), LA = linoleic acid (C18:2n6), RA = rumenic acid (c9,t11-CLA), VA = vaccenic acid (C18:1t11), SA = stearic acid (C18:0), PUFA = polyunsaturated fatty acids, MUFA = monounsaturated fatty acids, SFA = saturated fatty acids. References: $[89,90]$.

In addition to linseed supplementation, the inclusion of olive oil and soybean oil in the diet of ewes is able to increase the content of OLA and LA in the intramuscular fat of suckling lambs [89].

Other studies evinced that the inclusion of calcium in ewes' diet is effective to increase the content of SFA, especially PA, in the intramuscular fat of suckling lambs [89,91].

Finally, the inclusion of marine oils, a source of LC-PUFA, in the diet of ewes noticeably improved the content of EPA and DHA, but also that of c9,t11-CLA, and VA, in the intramuscular fat of suckling lambs [6]. However, the inclusion of marine oils and the excessive increase in PUFA in meat can adversely affect flavor and meat oxidative stability. These potential detrimental effects on flavor and shelf life should be considered when diets of ewes are formulated to improve nutritional features in lamb meat. 


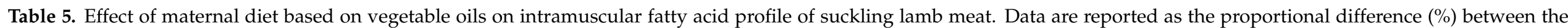
supplemented group and the non-supplemented control group.

\begin{tabular}{|c|c|c|c|c|c|c|c|c|c|c|c|c|c|}
\hline \multirow{2}{*}{ Breed } & \multirow{2}{*}{ Dietary Treatment $^{1}$} & \multirow{2}{*}{ Dose $^{2}$} & \multicolumn{10}{|c|}{ Intramuscular Fatty Acids of Suckling Lamb Meat ${ }^{3}$} & \multirow{2}{*}{ References } \\
\hline & & & VA & RA & LA & ALA & EPA & DHA & SFA & MUFA & PUFA & n6/n3 & \\
\hline \multirow{3}{*}{ Churra } & Olive oil & $63 \mathrm{~g} / \mathrm{d}$ & $57 \%$ & $3 \%$ & $-8 \%$ & $-16 \%$ & $-13 \%$ & $57 \%$ & $-5 \%$ & $11 \%$ & $-7 \%$ & $7 \%$ & \multirow{3}{*}{ [89] } \\
\hline & Soya oil & $63 \mathrm{~g} / \mathrm{d}$ & $176 \%$ & $97 \%$ & $7 \%$ & $-19 \%$ & $-32 \%$ & $176 \%$ & $-6 \%$ & $7 \%$ & $0.5 \%$ & $26 \%$ & \\
\hline & Linseed oil & $63 \mathrm{~g} / \mathrm{d}$ & $190 \%$ & $71 \%$ & $-2 \%$ & $103 \%$ & $35 \%$ & $190 \%$ & $-4 \%$ & $2 \%$ & $3 \%$ & $-43 \%$ & \\
\hline Churra & Extruded linseed & $189 \mathrm{~g} / \mathrm{d}$ & $321 \%$ & $247 \%$ & $9 \%$ & $309 \%$ & $223 \%$ & $102 \%$ & $-6 \%$ & $-9 \%$ & $76 \%$ & $-56 \%$ & [90] \\
\hline \multirow{3}{*}{ Churra } & LO (with 3\% linseed oil) & $3 \%$ linseed oil & $361 \%$ & $224 \%$ & $-6 \%$ & $56 \%$ & $-10 \%$ & $-39 \%$ & $-6 \%$ & $10 \%$ & $-5 \%$ & $-16 \%$ & \multirow{3}{*}{ [17] } \\
\hline & LO-Syn E & $\begin{array}{l}\mathrm{LO} \text { plus } 400 \mathrm{mg} / \mathrm{kg} \text { TMR of } \\
\text { synthetic vitamin E }\end{array}$ & $363 \%$ & $208 \%$ & $21 \%$ & $95 \%$ & $90 \%$ & $24 \%$ & $-14 \%$ & $8 \%$ & $29 \%$ & $-23 \%$ & \\
\hline & LO-Nat E & $\begin{array}{l}\mathrm{LO} \text { plus } 400 \mathrm{~g} / \mathrm{kg} \text { TMR of } \\
\text { natural vitamin } \mathrm{E})\end{array}$ & $446 \%$ & $226 \%$ & $-4 \%$ & $69 \%$ & $3 \%$ & $-37 \%$ & $-7 \%$ & $9 \%$ & $-2 \%$ & $-21 \%$ & \\
\hline Comisana & Extruded linseed & $190 \mathrm{~g} / \mathrm{d}$ & - & $47 \%$ & - & - & - & - & $-7 \%$ & $0.13 \%$ & $17 \%$ & $-31 \%$ & [11] \\
\hline
\end{tabular}

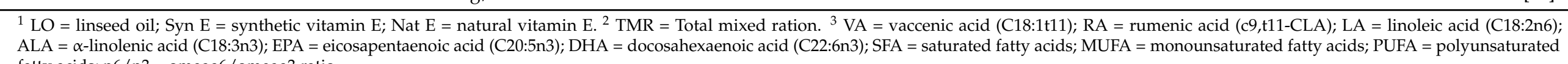
fatty acids; $\mathrm{n} 6 / \mathrm{n} 3=$ omega6 $/$ omega3 ratio. 


\section{Conclusions}

Suckling lambs' meat presents a FA composition that reflects that of the suckled milk. Suckling lamb meat, compared with that from artificially reared lambs, presents a more favorable nutritional FA profile since it contains more c9,t11-CLA, ALA, and LC-PUFA of the $\mathrm{n} 3$ family. From a nutritional point of view, suckling lamb meat from pasturefed mothers has interesting and distinguishing qualitative traits. When maternal diet is mainly based on hay and concentrate, the supplementation of vegetable oils, especially linseed or marine oils to the mothers, can be a strategy to ameliorate the meat FA profile of suckling lambs.

Author Contributions: Conceptualization, G.B. and A.N.; methodology, M.F.L. and G.P.; software, M.F.L.; validation, S.P.G.R.; data curation, M.F.L.; writing—original draft preparation, G.B.; writingall authors, G.B., M.F.L., S.P.G.R., G.P. and A.N.; funding acquisition, G.B. All authors have read and agreed to the published version of the manuscript.

Funding: This research was funded by RESTART-UNINUORO Project "Actions for the valorization of agroforestry resources in central Sardinia" Regione Autonoma della Sardegna, fondi FSC 2014-2020.

Data Availability Statement: The data presented in this study are available on request from the corresponding author.

Conflicts of Interest: The authors declare no conflict of interest.

\section{References}

1. Pulina, G.; Milán, M.J.; Lavín, M.P.; Theodoridis, A.; Morin, E.; Capote, J.; Thomas, D.L.; Francesconi, A.H.D.; Caja, G. Invited review: Current production trends, farm structures, and economics of the dairy sheep and goat sectors. J. Dairy Sci. 2018, 101, 6715-6729. [CrossRef] [PubMed]

2. Food and Agricultural Organization of the United Nations (FAO). Meat \& Meat Products. 2021. Available online: https: //www.fao.org/ag/againfo/themes/en/meat/home.html (accessed on 12 October 2021).

3. Nudda, A.; Battacone, G.; Boe, R.; Manca, M.G.; Rassu, S.P.G.; Pulina, G. Influence of outdoor and indoor rearing system of suckling lambs on fatty acid profile and lipid oxidation of raw and cooked meat. Ital. J. Anim Sci. 2013, 12, 459-467. [CrossRef]

4. Ferro, M.M.; Tedeschi, L.O.; Atzori, A.S. The comparison of the lactation and milk yield and composition of selected breeds of sheep and goats. Transl. Anim. Sci. 2017, 1, 498-506. [CrossRef] [PubMed]

5. Santos, V.A.C.; Silva, S.R.; Mena, E.G.; Azevedo, J.M.T.D. Live weight and sex effects on carcass and meat quality of “Borrego terrincho-PDO" suckling lambs. Meat Sci. 2007, 77, 654-661. [CrossRef] [PubMed]

6. Gallardo, B.; Gómez-Cortés, P.; Mantecón, A.R.; Juárez, M.; Manso, T.; De La Fuente, M.A. Effects of olive and fish oil Ca soaps in ewe diets on milk fat and muscle and subcutaneous tissue fatty-acid profiles of suckling lambs. Animal 2014, 8, 1178-1190. [CrossRef]

7. Nudda, A.; Atzori, A.S.; Boe, R.; Francesconi, A.H.D.; Battacone, G.; Pulina, G. Seasonal variation in the fatty acid profile in meat of Sarda suckling lambs. Ital. J. Anim. Sci. 2019, 18, 488-497. [CrossRef]

8. Lanza, M.; Bella, M.; Priolo, A.; Barbagallo, D.; Galofaro, V.; Landi, C.; Pennisi, P. Lamb meat quality as affected by a natural or artificial milk feeding regime. Meat Sci. 2006, 73, 313-318. [CrossRef] [PubMed]

9. Rassu, S.P.G.; Nudda, A.; Carzedda, C.; Battacone, G.; Bencini, R.; Pulina, G. A partial suckling regime increases milk production in Sarda dairy sheep without affecting meat quality of lambs. Small Rumin. Res. 2015, 125, 15-20. [CrossRef]

10. Napolitano, F.; Cifuni, G.F.; Pacelli, C.; Riviezzi, A.M.; Girolami, A. Effect of artificial rearing on lamb welfare and meat quality. Meat Sci. 2002, 60, 307-315. [CrossRef]

11. Fusaro, I.; Giammarco, M.; Chincarini, M.; Odintsov Vaintrub, M.; Palmonari, A.; Mammi, L.M.E.; Formigoni, A.; Di Giuseppe, L.; Vignola, G. Effect of ewe diet on milk and muscle fatty acid composition of suckling lambs of the protected geographical origin abbacchio romano. Animals 2020, 10, 25. [CrossRef]

12. Nudda, A.; Cannas, A.; Correddu, F.; Atzori, A.S.; Lunesu, M.F.; Battacone, G.; Pulina, G. Sheep and goats respond differently to feeding strategies directed to improve the fatty acid profile of milk fat. Animals 2020, 10, 1290. [CrossRef]

13. Nudda, A.; Correddu, F.; Cesarani, A.; Pulina, G.; Battacone, G. Functional odd-and branched-chain fatty acid in sheep and goat milk and cheeses. Dairy 2021, 2, 79-89. [CrossRef]

14. Nudda, A.; Battacone, G.; Bee, G.; Boe, R.; Castanares, N.; Lovicu, M.; Pulina, G. Effect of linseed supplementation of the gestation and lactation diets of dairy ewes on the growth performance and the intramuscular fatty acid composition of their lambs. Animal 2015, 9, 800-809. [CrossRef]

15. Addis, M.; Fiori, M.; Manca, C.; Riu, G.; Scintu, M.F. Muscle colour and chemical and fatty acid composition of "Agnello di Sardegna" PGI suckling lamb. Small Rumin. Res. 2013, 115, 51-55. [CrossRef] 
16. Nudda, A.; Battacone, G.; Boaventura Neto, O.; Cannas, A.; Francesconi, A.H.D.; Atzori, A.S.; Pulina, G. Feeding strategies to design the fatty acid profile of sheep milk and cheese. $R$ Bras Zootec. 2014, 43, 445-456. [CrossRef]

17. Gallardo, B.; Manca, M.G.; Mantecon, A.R.; Nudda, A.; Manso, T. Effects of linseed oil and natural or synthetic vitamin E supplementation in lactating ewes' diets on meat fatty acid profile and lipid oxidation from their milk fed lambs. Meat Sci. 2015, 102, 79-89. [CrossRef]

18. Calder, P.C. Functional roles of fatty acids and their effects on human health. J. Parenter. Enter. Nutr. 2015, 39, 18S-32S. [CrossRef] [PubMed]

19. Juárez, M.; Lam, S.; Bohrer, B.M.; Dugan, M.E.; Vahmani, P.; Aalhus, J.; Juárez, A.; López-Campos, O.; Prieto, N.; Segura, J. Enhancing the nutritional value of red meat through genetic and feeding strategies. Foods 2021, 10, 872. [CrossRef] [PubMed]

20. Lauritzen, L.; Hansen, H.S.; Jorgensen, M.H.; Michaelsen, K.F. The essentiality of long chain n-3 fatty acids in relation to development and function of the brain and retina. Prog. Lipid Res. 2001, 40,1-94. [CrossRef]

21. Koletzko, B.; Lien, E.; Agostoni, C.; Böhles, H.; Campoy, C.; Cetin, I.; Decsi, T.; Dudenhausen, J.W.; Dupont, C.; Forsyth, S.; et al. World association of perinatal medicine dietary guidelines working group. The roles of long-chain polyunsaturated fatty acids in pregnancy, lactation and infancy: Review of current knowledge and consensus recommendations. J. Perinatal Med. 2008, 36, 5-14. [CrossRef]

22. Cardi, E.; Corrado, G.; Cavaliere, M.; Grandina, G.; Pacchiarotti, C.; Rea, P.; Mazza, M.L.; Nardelli, F.; Agazie, E. Rezza-Cardi's diet as dietary treatment of short bowel syndrome. Gastroenterology 1998, 114, A869. [CrossRef]

23. Martino, F.; Bruno, G.; Aprigliano, D.; Agolini, D.; Guido, F.; Giardini, O.; Businco, L. Effectiveness of a home-made meat based formula (the Rezza-Cardi diet) as a diagnostic tool in children with food induced a topic dermatitis. Ped. Allergy Immunol. 1998, 9 , 192-196. [CrossRef] [PubMed]

24. Osorio, M.T.; Zumalacárregui, J.M.; Figueira, A.; Mateo, J. Fatty acid composition in subcutaneous, intermuscular and intramuscular fat deposits of suckling lamb meat: Effect of milk source. Small Rumin. Res. 2007, 73, 127-134. [CrossRef]

25. FDA. FDA Backgrounder, The Food Label, B99-5. 1999. Available online: http://www.fda.gov (accessed on 22 October 2021).

26. Serra, A.; Macciotta, N.P.P.; Mele, M.; Nudda, A.; Conte, G.; Secchiari, P. Effect of weight of slaughter and feeding regimen on conjugated linoleic acid and trans fatty acid content in lamb meat: A meta-analysis approach. Ital. J. Anim. Sci. 2009, 8, 540-542. [CrossRef]

27. Nudda, A.; McGuire, M.K.; Battacone, G.; Manca, M.G.; Boe, R.; Pulina, G. Documentation of fatty acid profiles in lamb meat and lamb-based infant foods. J. Food Sci. 2011, 76, H43-H47. [CrossRef]

28. Albenzio, M.; Santillo, A.; Avondo, M.; Nudda, A.; Chessa, S.; Pirisi, A.; Banni, S. Nutritional properties of small ruminant food products and their role on human health. Small Rumin. Res. 2016, 135, 3-12. [CrossRef]

29. Díaz, M.T.; Álvarez, I.; De la Fuente, J.; Sañudo, C.; Campo, M.M.; Oliver, M.A.; Font i Furnols, M.; Montossi, F.; San Julia 'n, R.; Nute, G.R.; et al. Fatty acid composition of meat from typical lamb production systems of Spain, United Kingdom, Germany and Uruguay. Meat Sci. 2005, 71, 256-263. [CrossRef]

30. Mele, M.; Serra, A.; Pauselli, M.; Luciano, G.; Lanza, M.; Pennisi, P.; Conte, G.; Taticchi, A.; Esposto, S.; Morbidini, L. The use of stoned olive cake and rolled linseed in the diet of intensively reared lambs: Effect on the intramuscular fatty-acid composition. Animal 2014, 8, 152-162. [CrossRef]

31. Kris-Etherton, P.M. Monounsaturated fatty acids and risk of cardiovascular disease. Circulation 1999, 100, 1253-1258. [CrossRef]

32. Sales-Campos, H.; Reis de Souza, P.; Crema Peghini, B.; Santana da Silva, J.; Ribeiro Cardoso, C. An overview of the modulatory effects of oleic acid in health and disease. Mini Rev. Med. Chem. 2013, 13, 201-210.

33. Dehghan, M.; Mente, A.; Zhang, X.; Swaminathan, S.; Li, W.; Mohan, V.; Iqbal, R.; Kumar, R.; Wentzel-Viljoen, E.; Rosengren, A.; et al. Associations of fats and carbohydrate intake with cardiovascular disease and mortality in 18 countries from five continents (PURE): A prospective cohort study. Lancet 2017, 390, 2050-2062. [CrossRef]

34. Carta, G.; Murru, E.; Banni, S.; Manca, C. Palmitic acid: Physiological role, metabolism and nutritional implications. Front. Physiol. 2017, 8, 902. [CrossRef]

35. Grundy, S.M. Influence of stearic acid on cholesterol metabolism relative to other long-chain fatty acids. Am. J. Clin. Nutr. 1994, 60, 986S-990S. [CrossRef]

36. Papotti, B.; Julve, J.; Poti, F.; Zanotti, I. Impact of dietary lipids on the reverse cholesterol transport: What we learned from animal studies. Nutrients 2021, 13, 2643. [CrossRef] [PubMed]

37. Simopoulos, A.P. The importance of the omega-6/omega-3 fatty acid ratio in cardiovascular disease and other chronic diseases Exp. Biol. Med. Maywood 2008, 233, 674-688. [CrossRef]

38. Jerónimo, E.; Alves, S.P.; Prates, J.A.; Santos-Silva, J.; Bessa, R.J. Effect of dietary replacement of sunflower oil with linseed oil on intramuscular fatty acids of lamb meat. Meat Sci. 2009, 83, 499-505. [CrossRef] [PubMed]

39. Warren, H.E.; Scollan, N.D.; Enser, M.; Hughes, S.I.; Richardson, R.I.; Wood, J.D. Effects of breed and a concentrate or grass silage diet on beef quality in cattle of 3 ages. I: Animal performance, carcass quality and muscle fatty acid composition. Meat Sci. 2008, 78, 256-269. [CrossRef]

40. Tallima, H.; El Ridi, R. Arachidonic acid: Physiological roles and potential health benefits-A review. J. Adv. Res. 2018, 11, 33-41. [CrossRef]

41. Kursun, O.; Yemisci, M.; van den Maagdenberg, A.M.; Karatas, H. Migraine and neuroinflammation: The inflammasome perspective. J. Headache Pain 2021, 22, 55. [CrossRef] [PubMed] 
42. Rapoport, S.I.; Rao, J.S.; Igarashi, M. Brain metabolism of nutritionally essential polyunsaturated fatty acids depends on both the diet and the liver. Prostaglandins Leukot. Essent Fatty Acids 2007, 77, 251-261. [CrossRef]

43. Ran-Ressler, R.R.; Khailova, L.; Arganbright, K.M.; Adkins-Rieck, C.K.; Jouni, Z.E.; Koren, O.; Ley, R.E.; Brenna, T.; Dvorak, B. Branched chain fatty acids reduce the incidence of necrotizing enterocolitis and alter gastrointestinal microbial ecology in a neonatal rat model. PLoS ONE 2011, 6, e29032. [CrossRef]

44. Ran-Ressler, R.R.; Bae, S.; Lawrence, P.; Wang, D.H.; Brenna, J.T. Branched-chain fatty acid content of foods and estimated intake in the USA. Br. J. Nutr. 2014, 112, 565-572. [CrossRef] [PubMed]

45. Yang, Z.; Liu, S.; Chen, X.; Chen, H.; Huang, M.; Zheng, J. Induction of apoptotic cell death and in vivo growth inhibition of human cancer cells by a saturated branched-chain fatty acid, 13-methyltetradecanoic acid. Cancer Res. 2000, 60, 505-509. [PubMed]

46. Wongtangtintharn, S.; Oku, H.; Iwasaki, H.; Toda, T. Effect of branched-chain fatty acids on fatty acid biosynthesis of human breast cancer cells. J. Nutr. Sci. Vitaminol. 2004, 50, 137-143. [CrossRef]

47. Warensjö, E.; Jansson, J.H.; Berglund, L.; Boman, K.; Ahren, B.; Weinehall, L.; Lindahl, B.; Hallmans, G.; Vessby, B. Estimated intake of milk fat is negatively associated with cardiovascular risk factors and does not increase the risk of a first acute myocardial infarction. A prospective case-control study. Br. J. Nutr. 2004, 91, 635-642. [CrossRef] [PubMed]

48. Sun, Q.; Ma, J.; Campos, H.; Hankinson, S.E.; Manson, J.E.; Stampfer, M.J.; Rexrode, K.M.; Willett, W.C.; Hu, F.B. A prospective study of trans fatty acids in erythrocytes and risk of coronary heart disease. Circulation 2007, 115, 1858-1865. [CrossRef] [PubMed]

49. Warensjö, E.; Jansson, J.H.; Cederholm, T.; Boman, K.; Eliasson, M.; Hallmans, G.; Johansson, I.; Sjögren, P. Biomarkers of milk fat and the risk of myocardial infarction in men and women: A prospective, matched case-control study. Am. J. Clin. Nutr. 2010, 92, 194-202. [CrossRef]

50. Khaw, K.T.; Friesen, M.D.; Riboli, E.; Luben, R.; Wareham, N. Plasma phospholipid fatty acid concentration and incident coronary heart disease in men and women: The EPIC-Norfolk prospective study. PLoS Med. 2012, 9, e1001255. [CrossRef]

51. Jenkins, B.; West, J.A.; Koulman, A. A review of odd-chain fatty acid metabolism and the role of pentadecanoic acid (C15: 0) and heptadecanoic acid (C17: 0) in health and disease. Molecules 2015, 20, 2425-2444. [CrossRef]

52. Hodge, A.M.; English, D.R.; O’Dea, K.; Sinclair, A.J.; Makrides, M.; Gibson, R.A.; Giles, G.G. Plasma phospholipid and dietary fatty acids as predictors of type 2 diabetes: Interpreting the role of linoleic acid. Am. J. Clin. Nutr. 2007, 86, 189-197. [CrossRef]

53. Krachler, B.; Norberg, M.; Eriksson, J.W.; Hallmans, G.; Johansson, I.; Vessby, B.; Weinehall, L.; Lindahl, B. Fatty acid profile of the erythrocyte membrane preceding development of Type 2 diabetes mellitus. Nutr. Metab. Cardiovasc. Dis. 2008, 18, 503-510. [CrossRef] [PubMed]

54. Forouhi, N.G.; Koulman, A.; Sharp, S.J.; Imamura, F.; Kröger, J.; Schulze, M.B.; Crowe, F.L.; Huerta, J.M.; Guevara, M.; Beulens, J.W.J.; et al. Differences in the prospective association between individual plasma phospholipid saturated fatty acids and incident type 2 diabetes: The EPIC-InterAct case-cohort study. Lancet Diabetes Endocrinol. 2014, 2, 810-818. [CrossRef]

55. Imamura, F.; Fretts, A.; Marklund, M.; Ardisson Korat, A.V.; Yang, W.S.; Lankinen, M.; Qureshi, W.; Helmer, C.; Chen, T.A.; Wong, K.; et al. Fatty acid biomarkers of dairy fat consumption and incidence of type 2 diabetes: A pooled analysis of prospective cohort studies. PLoS Med. 2018, 15, e1002670. [CrossRef] [PubMed]

56. Venn-Watson, S.; Lumpkin, R.; Dennis, E.A. Efficacy of dietary odd-chain saturated fatty acid pentadecanoic acid parallels broad associated health benefits in humans: Could it be essential? Sci. Rep. 2020, 10, 1-14. [CrossRef]

57. Moloney, F.; Yeow, T.P.; Mullen, A.; Nolan, J.J.; Roche, H.M. Conjugated linoleic acid supplementation, insulin sensitivity, and lipoprotein metabolism in patients with type 2 diabetes mellitus. Am. J. Clin. Nutr. 2004, 80, 887-895. [CrossRef] [PubMed]

58. Bhattacharya, A.; Banu, J.; Rahman, M.; Causey, J.; Fernandes, G. Biological effects of conjugated linoleic acids in health and disease. J. Nutr. Biochem. 2006, 17, 789-810. [CrossRef]

59. Sofi, F.; Rapini, D.; Innocenti, G.; Abbate, R.; Gensini, G.F.; Casini, A. Dietary intake of trans fatty acids as a cardiovascular risk factor in a population of Italian teenagers. Cardiol. Young 2009, 19, 589-593. [CrossRef] [PubMed]

60. Tricon, S.; Burdge, G.C.; Kew, S.; Banerjee, T.; Russell, J.J.; Jones, E.L.; Grimble, R.F.; Williams, C.M.; Yaqoob, P.; Calder, P.C. Opposing effects of cis-9, trans-11 and trans-10, cis-12 conjugated linoleic acid on blood lipids in healthy humans. Am. J. Clin. Nutr. 2004, 80, 614-620. [CrossRef] [PubMed]

61. Gaullier, J.M.; Halse, J.; Høye, K.; Kristiansen, K.; Fagertun, H.; Vik, H.; Gudmundsen, O. Supplementation with conjugated linoleic acid for 24 months is well tolerated by and reduces body fat mass in healthy, overweight humans. J. Nutr. 2005, 135, 778-784. [CrossRef] [PubMed]

62. Pintus, S.; Murru, E.; Carta, G.; Cordeddu, L.; Batetta, B.; Accossu, S.; Pistis, D.; Uda, S.; Ghiani, M.E.; Mele, M.; et al. Sheep cheese naturally enriched in $\alpha$-linolenic, conjugated linoleic and vaccenic acids improves the lipid profile and reduces anandamide in the plasma of hypercholesterolaemic subjects. Br. J. Nutr. 2013, 109, 1453-1462. [CrossRef] [PubMed]

63. de Almeida, M.M.; Luquetti, S.C.; Sabarense, C.M.; do Amaral Corrêa, J.O.; dos Reis, L.G.; Santos da Conceição, E.P.; Lisboa, P.C.; de Moura, E.G.; Gameiro, J.; da Gama, M.A.; et al. Butter naturally enriched in cis-9, trans-11 CLA prevents hyperinsulinemia and increases both serum HDL cholesterol and triacylglycerol levels in rats. Lipids Health Dis. 2014, 13, 200. [CrossRef] [PubMed]

64. Virsangbhai, C.K.; Goyal, A.; Tanwar, B.; Sihag, M.K. Potential health benefits of conjugated linoleic acid: An important functional dairy ingredient. Eur. J. Nutr. Food Saf. 2020, 11, 200-213. [CrossRef] 
65. Domínguez, R.; Pateiro, M.; Gagaoua, M.; Barba, F.J.; Zhang, W.; Lorenzo, J.M. A comprehensive review on lipid oxidation in meat and meat products. Antioxidants 2019, 8, 429. [CrossRef]

66. Cometto-Muñiz, J.E.; Abraham, M.H. Odor detection by humans of lineal aliphatic aldehydes and helional as gauged by dose-response functions. Chem. Senses 2010, 35, 289-299. [CrossRef] [PubMed]

67. D'Alessandro, A.G.; Maiorano, G.; Kowaliszyn, B.; Loiudice, P.; Martemucci, G. How the nutritional value and consumer acceptability of suckling lambs meat is affected by the maternal feeding system. Small Rumin. Res. 2012, 106, 83-91. [CrossRef]

68. Joy, M.; Sanz, A.; Ripoll, G.; Panea, B.; Ripoll-Bosch, R.; Blasco, I.; Alvarez-Rodriguez, J. Does forage type (grazing vs. hay) fed to ewes before and after lambing affect suckling lambs performance, meat quality and consumer purchase intention? Small Rumin. Res. 2012, 104, 1-9. [CrossRef]

69. Pulina, G.; Atzori, A.S.; Dimauro, C.; Ibba, I.; Gaias, G.F.; Correddu, F.; Nudda, A. The milk fingerprint of Sardinian dairy sheep: Quality and yield of milk used for Pecorino Romano PDO cheese production on population-based 5-year survey. Ital. J. Anim. Sci. 2021, 20, 171-180. [CrossRef]

70. Wilches, D.; Rovira, J.; Jaime, I.; Palacios, C.; Lurueña-Martínez, M.A.; Vivar-Quintana, A.M.; Revilla, I. Evaluation of the effect of a maternal rearing system on the odour profile of meat from suckling lamb. Meat Sci. 2011, 88, 415-423. [CrossRef] [PubMed]

71. Scerra, M.; Caparra, P.; Foti, F.; Galofaro, V.; Sinatra, M.C.; Scerra, V. Influence of ewe feeding systems on fatty acid composition of suckling lambs. Meat Sci. 2007, 76, 390-394. [CrossRef]

72. Dervishi, E.; Joy, M.; Alvarez-Rodriguez, J.; Serrano, M.; Calvo, J.H. The forage type (grazing versus hay pasture) fed to ewes and the lamb sex affect fatty acid profile and lipogenic gene expression in the longissimus muscle of suckling lambs. J. Anim. Sci. 2012, 90, 54-66. [CrossRef]

73. Joy, M.; Ripoll, G.; Molino, F.; Dervishi, E.; Alvarez-Rodriguez, J. Influence of the type of forage supplied to ewes in pre-and post-partum periods on the meat fatty acids of suckling lambs. Meat Sci. 2012, 90, 775-782. [CrossRef] [PubMed]

74. Parrini, S.; Sirtori, F.; Acciaioli, A.; Becciolini, V.; Crovetti, A.; Bonelli, A.; Franci, O.; Bozzi, R. Effect of farming system on meat traits of native Massese suckling lamb. Ital. J. Anim. Sci. 2021, 20, 71-83. [CrossRef]

75. Griinari, J.M.; Corl, B.A.; Lacy, S.H.; Chouinard, P.Y.; Nurmela, K.V.; Bauman, D.E. Conjugated linoleic acid is synthesized endogenously in lactating dairy cows by delta(9)-desaturase. J. Nutr. 2000, 130, 2285-2291. [CrossRef] [PubMed]

76. Wachira, A.M.; Sinclair, L.A.; Wilkinson, R.G.; Hallett, K.; Enser, M.; Wood, J.D. Rumen biohydrogenation of n-3 polyunsaturated fatty acids and their effects on microbial efficiency and nutrient digestibility in sheep. J. Agric. Sci. 2000, 135, 419-428. [CrossRef]

77. Lock, A.L.; Bauman, D.E. Modifying milk fat composition of dairy cows to enhance fatty acids beneficial to human health. Lipids 2004, 39, 1197-1206. [CrossRef] [PubMed]

78. Wachira, A.M.; Sinclair, L.A.; Wilkinson, R.G.; Enser, M.; Wood, J.D.; Fisher, A.V. Effects of dietary fat source and breed on the carcass composition, n-3 polyunsaturated fatty acid and conjugated linoleic acid content of sheep meat and adipose tissue. Br. J. Nutr. 2002, 88, 697-709. [CrossRef]

79. Addis, M.; Cabiddu, A.; Pinna, G.; Decandia, M.; Piredda, G.; Pirisi, A.; Molle, G. Milk and cheese fatty acid composition of sheep fed different Mediterranean forages with particular reference to conjugated linoleic acid cis-9, trans-11. J. Dairy Sci. 2005, 88, 3443-3454. [CrossRef]

80. Cabiddu, A.; Decandia, M.; Addis, M.; Piredda, G.; Pirisi, A.; Molle, G. Managing mediterranean pastures in order to enhance the level of beneficial fatty acids in sheep milk. Small Rumin. Res. 2005, 59, 169-180. [CrossRef]

81. Nudda, A.; Mele, M.; Battacone, G.; Usai, M.G.; Macciotta, N.P.P. Comparison of conjugated linoleic acid (CLA) content in milk of ewes and goats with the same dietary regimen. Ital. J. Anim. Sci. 2003, 2, 515-517.

82. Freitas de Melo, A.; Ungerfeld, R. Artificial weaning in sheep: Stress response and animal welfare. Review. Rev. Mex. Cienc. Pecu 2016, 7, 361-375. [CrossRef]

83. Margetin, M.; Apolen, D.; Oravcova, M.; Avrišinová, K.; Peškovičová, D.; Luptáková, L.; Krupová, Z.; Bučko, O.; Blaško, J. Fatty acids profile of intramuscular fat in light lambs traditionally and artificially reared. J. Cent. Eur. Agric. 2014, 15, 117-129. [CrossRef]

84. Manca, M.G.; Battacone, G.; Boe, R.; Spanu, G.; Nudda, A. Effect of natural and artificial milk on long chain fatty acid of meat from Sarda suckling lambs. In Proceedings of the 19 Congress of Animal Science and Production Association (ASPA), Cremona, Italy, 7-10 July 2011.

85. Osorio, M.T.; Zumalacárregui, J.M.; Cabeza, E.A.; Figueira, A.; Mateo, J. Effect of rearing system on some meat quality traits and volatile compounds of suckling lamb meat. Small Rumin. Res. 2008, 78, 1-12. [CrossRef]

86. Cifuni, G.F.; Braghieri, A.; Riviezzi, A.M.; Girolami, A.; Napolitano, F. Artificial rearing and intramuscular fatty acid composition of unweaned lambs. Ital. J. Food Sci. 2003, 15, 241-248.

87. Capper, J.L.; Wilkinson, R.G.; Mackenzie, A.M.; Sinclair, L.A. The effect of fish oil supplementation of pregnant and lactating ewes on milk production and lamb performance. Animal 2007, 6, 889-898. [CrossRef]

88. Or-Rashid, M.M.; Fisher, R.; Karrow, N.; Alzahal, O.; McBride, B.W. Fatty acid profile of colostrum and milk of ewes supplemented with fish meal and the subsequent plasma fatty acid status of their lambs. J. Anim. Sci. 2010, 88, 2092-2102. [CrossRef] [PubMed]

89. Manso, T.; Bodas, R.; Vieira, C.; Mantecón, A.R.; Castro, T. Feeding vegetable oils to lactating ewes modifies the fatty acid profile of suckling lambs. Animal 2011, 5, 1659-1667. [CrossRef] 
90. Gómez-Cortés, P.; Gallardo, B.; Mantecón, A.R.; Juárez, M.; De La Fuente, M.A.; Manso, T. Effects of different sources of fat (calcium soap of palm oil vs. extruded linseed) in lactating ewes' diet on the fatty acid profile of their suckling lambs. Meat Sci. 2014, 96, 1304-1312. [CrossRef] [PubMed]

91. Lurueña-Martínez, M.A.; Palacios, C.; Vivar-Quintana, A.M.; Revilla, I. Effect of the addition of calcium soap to ewes' diet on fatty acid composition of ewe milk and subcutaneous fat of suckling lambs reared on ewe milk. Meat Sci. 2010, 84, 677-683. [CrossRef] 